\title{
Impact of Socio-Economic Status on Academic Performance among Ninth Grade Secondary School Students in Two Diocesan Colleges in Mauritius
}

\author{
Steven Ludovic Mootooveeren Mootoocurpen Goonesh Kumar Bahadur ${ }^{*}$ \\ Dorothy Cooshna-Naik \\ Centre for Innovative and Lifelong Learning (CILL), University of Mauritius, Ebene, Mauritius \\ * E-mail of the corresponding author: g.bahadur@uom.ac.mu
}

\begin{abstract}
Over recent years, there has been a decrease in the performance of students especially in mixed ability colleges in Mauritius. This study investigated the relationship between academic performance and the socio-economic status (SES). The findings showed that the students' performances at schools were affected by social, cultural and economic factors. Social factors like indiscipline, sickness, lack of interest in school, broken families and substance abuse were the main factors identified to affect negatively the performance of students in schools. It was also observed that due the lack of parents involvement, the academic performance of the students were also affected.
\end{abstract}

Keywords: Socio-economic Status, social factors, cultural factors, economic factors, academic performance DOI: $10.7176 / \mathrm{JEP} / 12-17-04$

Publication date: June $30^{\text {th }} 2021$

\section{Introduction}

One of the most discussed concerns among professionals of the educational sector is the relationship between the academic performance and the socio-economic status (SES) of pupils. The link between socio-economic status and the academic performance of students has been widely studied in social sciences. SES being a common variable used in educational research (Sirin, 2005) has been conceptualized in different ways in the literature. SES is seen as a measure of one's combined economic status and social status (Baker, 2014). Other indicators for SES include education, social class or income (Darin-Mattsson, Fors \& Kåreholt, 2017). For the purpose of this current study, we consider SES as achievement of families in terms of income, educational achievement and their respective occupation.

Global studies demonstrate that SES factors that have significant impacts on the students' performance in schools include poverty, the level of education of students' parents, parental income, indiscipline and lack of motivation. The relationship between academic performance and SES as discussed in the literature ranges from being very strong to moderate. Several researchers contend that children from SES households and communities are exposed to poor neighborhoods and therefore are more likely to be deprived materially and emotionally (Alika; Morgan, Farkas, Hillemeier, \& Maczuga, 2009; Alika \& Edosa, 2012). This subsequently have a negative impact on their academic performance.

It is further noted that schools located in low SES communities often lack resources, which have a direct negative influence on students' progress and outcomes (Aikens \& Barbarin, 2008). The 'Equity and Quality in Education: Supporting Disadvantaged Students and Schools', a report published by OECD in 2012 highlights the importance of school structures, resources and pedagogical practices' in determining students' learning, motivation and sense of belonging.

The educational background of parents play a major role in their wards' academic performance (Grissmer, Kirby, Berends \& Williamson, 1994; Okantey, 2008). Parents with a solid educational background possess the potential to have an increased income and are more likely to show involvement and concern on the achievement standards of their children's school (Okantey, 2008). Parents of high socio-economic status tend to have the ability to support financially and morally their children, which in turn could improve the performance of students in school (Makewa et al. 2012).

Ellis (2008), Sang (2015) and D'Mello et al. (2018) express the importance of self-esteem in academic achievement. Mosha (2017) contend that students from disadvantaged SES tend to develop low self-esteem and a lack of confidence due to several emotionally related issues. This negatively affects the success of the students at school.

Several researchers (Zimring, 1998; Steinberg, 2005; Temitope \& Christy, 2015; Mosha, 2017; Bankole, 2019) have found that there exists a relationship between peer pressure and students' academic performance. According to Steinberg (2005), a student who is negatively influenced by his peers would often have a poor academic performance. Likewise, positive peer influence results in students' academic vigor and motivation for achievement (Lashbrook, 2000, Olalekan, 2016). 
In Mauritius, the academic performance of students in secondary schools, is a matter of great concern for parents and has been on the agenda of the government since a long time. The quality of education at secondary level has become a major problem especially with the re-introduction of obtaining 5 credits at School Certificate "O" level to secure a place in Grade 12. Indeed, the decreasing performance of students especially in mixed ability colleges have increased. Data collected from Statistical office (CSO, 2020) shows that there is a complete decline in academic performances of students for both female and male gender. There has been a drop of $4.1 \%$ over the past five years in academic performance. One of the factors that could have contributed to this drop in the academic performance is the SES background of the students.

A review of the literature shows that many studies have been carried out to examine the different SES factors that influence student's performances in schools. However, such studies on how SES affects the students' performance in schools have not been carried out in Mauritius. This study aims to investigate the academic performance of students from different SES background and explores how their performance varies socially. The extent to which factors such as family, personal and other circumstantial factors impact on the students' academic performance is discussed.

This research used data on students' academic performance from different SES backgrounds and also considered the performance of students in national examinations in their Grade 9 for their National Certificate of Education (NCE) in the academic year 2020.

The following objectives steered this study:

i) To determine how the students' school performance were affected by social factors.

ii) To investigate the impact of economic factors on students' school performance.

iii) To evaluate how cultural factors affect students' school performance.

iv) To establish ways to enhance students' academic performance

v) To propose a new leadership model of learning and teaching in these two colleges considered for this study.

\section{Methodology}

For this study, the following hypotheses were used to address socio-economic relationship with educational attainment:

- Hypothesis 1: There would be significant difference on academic achievement of students between high and low SES.

- Hypothesis 2: There would be significant difference on academic achievement of students from high and low income families.

- Hypothesis 3: There would be significant difference on pupils' performance and their socioeconomic family background.

The study was carried out in two diocesan secondary schools in an urban area on the west side of Mauritius. The two secondary schools fall in a region considered to have low economic status students and where the academic performances of the two colleges have considerably fallen over the recent five years (MES, 2020). A sample size of 250 people consisting of 200 ninth grade pupils, 45 teachers, 2 deputy rectors and 3 rectors was used.

Questionnaires were administered to teachers, deputy rectors, rectors and the ninth grade pupils and interviews were carried out with parents. The questionnaires gathered information on the socio-economic, family background, peer pressure and cultural factors affecting pupils' performance. Income of the parents, their level of education and occupation were also used as a measure of economic status of the family. The questionnaire consisted of both Likert-style, multiple choice questions, open ended and closed ended questions.

Additionally, the data set consisted of the Grades 7 to 9 examination results of the students. These results, which were made available by the school management, were helpful in determining whether there is a relationship between SES and students' academic performance over a period of time. A pilot study of the survey was carried out to determine the relevance and reliability of the questions.

\section{Results and Analysis}

3.1 Ethnicity

The study sought to determine if ethnicity of the students had an impact on the students' performance (Table 1). 
Table 1. Religion of Students

\begin{tabular}{|lll|l|l|l|}
\hline Religion & & & & \\
\hline & & Frequency & Percent & Valid Percent & $\begin{array}{l}\text { Cumulative } \\
\text { Percent }\end{array}$ \\
\hline Valid & Islam & 37 & 21.1 & 22.4 & 22.4 \\
\cline { 2 - 6 } & Roman Catholic & 82 & 46.9 & 49.7 & 72.1 \\
\cline { 2 - 6 } & Hinduism & 42 & 24.0 & 25.5 & 97.6 \\
\cline { 2 - 6 } & Atheist & 4 & 2.3 & 2.4 & 100.0 \\
\cline { 2 - 6 } & Total & 165 & 94.3 & 100.0 & \\
\hline Missing & 10 & 5.7 & & \\
\hline Total & 175 & 100.0 & & \\
\hline
\end{tabular}

Table 1 shows the majority of students were of Roman Catholic (46.9\%), followed by Hindus (24\%) and of Islamic faith $(21.1 \%)$. The study aimed at determining if ethnicity affected students' performance. The above data was cross-tabulated with the students' academic average marks obtained during the survey study (Table 2).

Table 2. Correlation of ethnicity and students' performance

\begin{tabular}{|l|l|l|l|}
\hline \multicolumn{2}{|l|}{ Correlations } & \multicolumn{2}{l|}{} \\
\hline \multirow{3}{*}{ Religion } & Pearson Correlation & 1 & .038 \\
\cline { 2 - 4 } & Sig. (2-tailed) & & .660 \\
\cline { 2 - 4 } & $\mathrm{N}$ & 165 & 133 \\
\hline \multirow{3}{*}{ Average Score } & Pearson Correlation & .038 & 1 \\
\cline { 2 - 4 } & Sig. (2-tailed) & .660 & \\
\cline { 2 - 4 } & $\mathrm{N}$ & 133 & 140 \\
\hline
\end{tabular}

A Pearson correlation coefficient of 0.038 was obtained showing no significant relationship between ethnicity and students' performance hence going in line with Runs et al. (2018) who found that there is no significant relationship between ethnicity and academic performance.

\subsection{Social factors affecting pupil's academic performance}

Table 3 looks at the social factors that affect the performance of the students academically in these two diocesan colleges under study.

Table 3. Correlation of ethnicity and students' performance

\begin{tabular}{|c|c|c|}
\hline Factor & Number & Percentage (\%) \\
\hline Unexpected reasons & 3 & 1.2 \\
\hline Indiscipline & 165 & 66.5 \\
\hline Sickness & 8 & 3.2 \\
\hline Lack of interest & 13 & 5.2 \\
\hline Substance Abuse & 43 & 17.4 \\
\hline Broken Family & 16 & 6.5 \\
\hline Total & 248 & 100.0 \\
\hline
\end{tabular}

3.3 Economic factors affecting the performance of students

The purpose here was to find out the economic factors that affects students' performance. The findings from Table 4 shows that $41 \%$ of the pupils failed in their recent examinations. In this research study, the socioeconomic status of the parent was investigated and the results were cross-tabulated with the pupils' performance in their examinations. The data analysis was carried out in two stages:

(i) Formation of socio-economic classes (high socio-economic status, middle socio-economic status and lower socio-economic status)

(ii) Determination of correlating coefficient to find if a relationship between SES and average scores existed 
Table 4. Pupils distribution of marks

\begin{tabular}{|c|c|c|c|c|c|c|}
\hline \multirow{2}{*}{ Mean Score } & \multicolumn{2}{|c|}{$\boldsymbol{N}$} & \multicolumn{2}{c|}{$\%$} & \multicolumn{2}{c|}{ Overall count } \\
\cline { 2 - 7 } & Male & Female & Male & Female & N & \multicolumn{1}{c|}{} \\
\hline $0-20$ & 2 & - & 3.0 & - & 2 & 4.0 \\
\hline $21-40$ & 37 & 23 & 51.0 & 30.0 & 60 & 24.0 \\
\hline $41-50$ & 23 & 13 & 32.0 & 17.0 & 36 & 23.0 \\
\hline $51-60$ & 9 & 25 & 13.0 & 32.0 & 34 & 12.0 \\
\hline $61-70$ & 1 & 16 & 1.0 & 21.0 & 17 & $\mathbf{1 0 0 . 0}$ \\
\hline Total & $\mathbf{7 2}$ & $\mathbf{7 7}$ & $\mathbf{1 0 0 . 0}$ & $\mathbf{1 0 0 . 0}$ & $\mathbf{1 4 9}$ & \\
\hline
\end{tabular}

It was found that $42 \%$ pupils were from high SES, $28 \%$ were from middle SES and $30 \%$ were from lower SES. The academic performance of the pupils was correlated with their parental SES using Pearson correlation on SPSS software, Table 5.

Table 5. Correlation between students' performance and their parents SES

\begin{tabular}{|l|l|l|}
\hline \multirow{3}{*}{ Parents SES } & Pearson Correlation & $.204^{*}$ \\
\cline { 2 - 3 } & Sig. (2-tailed) & .016 \\
\cline { 2 - 3 } & $\mathrm{N}$ & 140 \\
\hline
\end{tabular}

*. Correlation is significant at the 0.05 level (2-tailed).

A correlation coefficient of 0.204 was obtained, whose significance at the 0.05 level implied there was an association between pupil's academic performance and their parental SES. This means that there was a relationship between the pupils' low performance and their parental SES but their poor performances could not be only due to their low SES. However, these findings also indicated that pupils' academic performance could not be linked only to their SES but there were also other underlying reasons for their low academic performances. Hardy (2006) mentions that the SES of one pupil may not be the only determining factor of academic success. In addition, a study carried out in Nigeria (Machebe \& Ifelunni, 2014) on the parental social economic status showed the opposite results from this current study carried out in Mauritius. They found no significant effect on the parental socio-economic status and parental educational background on academic performance of their children.

The background of the family members of the students was also investigated (Table 6). The data in Table 6 indicates that $38 \%$ of the parents of low SES did only up to primary education and $23 \%$ left school while $10 \%$ never went to school. The research data further demonstrated that the majority of parents of low SES reached only up to primary level of formal schooling with $10 \%$ up to secondary while only one guardian reached primary school.

Table 6. Educational background of the family of the students

\begin{tabular}{|c|c|c|c|c|c|c|c|}
\hline \multicolumn{2}{|c|}{ Status } & \multicolumn{2}{|c|}{ Low SES } & \multicolumn{2}{|c|}{ Middle SES } & \multicolumn{2}{|c|}{ High SES } \\
\hline \multirow{2}{*}{\multicolumn{2}{|c|}{ Responses }} & \multicolumn{2}{|c|}{$\mathrm{N}=52, \mathrm{~F}(\%)$} & \multicolumn{2}{|c|}{$\mathrm{N}=49, \mathrm{~F}(\%)$} & \multicolumn{2}{|c|}{$\mathrm{N}=74, \mathrm{~F}(\%)$} \\
\hline & & $\mathbf{P}$ & $\mathbf{G}$ & $\mathbf{P}$ & $\mathbf{G}$ & $\mathbf{P}$ & $\mathbf{G}$ \\
\hline \multirow{3}{*}{$\begin{array}{c}\text { School } \\
\text { Attendance } \\
\text { Status }\end{array}$} & At school & $9(17 \%)$ & - & $8(16 \%)$ & $1(2 \%)$ & $17(23 \%)$ & $3(4 \%)$ \\
\hline & Left school & $12(23 \%)$ & - & $2(4 \%)$ & - & - & - \\
\hline & Never went to school & $5(10 \%)$ & - & - & - & - & - \\
\hline \multirow{3}{*}{$\begin{array}{l}\text { Highest formal } \\
\text { level of } \\
\text { schooling } \\
\text { completed }\end{array}$} & Primary & $20(38 \%)$ & $1(2 \%)$ & $8(16 \%)$ & - & $4(5 \%)$ & - \\
\hline & Secondary & $5(10 \%)$ & - & $17(35 \%)$ & $2(4 \%)$ & $18(24 \%)$ & - \\
\hline & $\begin{array}{c}\text { Tertiary (University } \\
\text { degree / diploma) }\end{array}$ & - & - & $10(20 \%)$ & $1(2 \%)$ & $29(39 \%)$ & $3(4 \%)$ \\
\hline
\end{tabular}

*Source: Data includes Mother, Father (P) and guardian (G) when compared to low, middle and high SES.

Furthermore, for Middle SES, the status of their school attendance revealed that only $16 \%$ stopped at primary level, $35 \%$ went to secondary level and $20 \%$ went to university level. The study also found that family members in the Middle SES had graduated from the university (20\%). Parents in the high socioeconomic status category were found to have higher level of education than those of low or middle SES. As indicated, $43 \%$ went to university (including guardians) having a degree, postgraduate certificate or a university diploma and $24 \%$ went up to secondary schooling.

These results obtained above were cross-tabulated with the pupil's average scores and the results obtained established a weak positive correlation between their academic achievement and the level of education of their parents (Pearson coefficient $r=0.20$ ). The results demonstrated that there was no significant evidence between sole interrelationships of academic performance and parental educational background.

However, parents' level of education do influence the pupil's academic performance, as an uneducated parent may not be in a good position to give proper assistance to their children. The findings of this study go in line with Ngatiari (2011) who hypothesized that parental level of education do enhance children's learning and their academic achievement positively (Ayoo, 2002). This study also tried to investigate how much parental 
involvement in school activities influenced their learning outcomes. The majority of the respondents affirmed that parental involvement do encourage children to do better but different responses were obtained, in both colleges. The response rate was higher in the Girls College (63\%) compared to the boys college $(47 \%)$ of parental involvement. Musgrave (2009) established that parental involvement in school activities do enhance pupils' academic achievement.

This research work has conceptualized that parental occupation and their implication in their children academic performance would be a significant variable to determine the SES of parents and academic success. This study investigated on the occupation of the pupil's parents and the effect on their academic performances. Parental occupation are among the major factors affecting student's performance academically (Murithi, 2015; Usaini \& Abubakar, 2015). From the study carried out, the responses of the students when asked whether their parents' occupation affected their education, most were affirmative. Most of those coming from high SES and middle SES had parents with permanent jobs (72.6\%) while a minority from low SES either were on contract $(16.6 \%)$ or involved in casual works $(10.9 \%)$. The students also responded that even $41.7 \%$ of their parents were always there for them, the majority were described as being busy $(58.2 \%)$ and $58.3 \%$ among these students rarely got the emotional support wanted. Like the students, the teachers also noted that some parental occupations deprived their children from giving them time for academic progress or any supports they needed.

Pearson's correlation coefficient was calculated to determine whether there existed a relationship between the pupil's academic performance and their parents' occupation (Table 7). The correlation coefficient, $r$ was 0.04 that reflected a weak correlation indication that these two are not significantly linked.

Table 7. Parental occupation vs academic average score

\begin{tabular}{|c|c|c|c|c|c|}
\hline \multicolumn{6}{|c|}{ Parent's Occupation } \\
\hline & & Frequency & Percent & Valid Percent & Cumulative Percent \\
\hline \multirow[t]{8}{*}{ Valid } & Business & 36 & 20.6 & 20.6 & 20.6 \\
\hline & Professional & 46 & 26.3 & 26.3 & 46.9 \\
\hline & Managerial and technical & 20 & 11.4 & 11.4 & 58.3 \\
\hline & $\begin{array}{l}\text { Clerical and minor supervisory } \\
\text { and skilled manual }\end{array}$ & 52 & 29.7 & 29.7 & 88.0 \\
\hline & Semi-Skilled manual & 15 & 8.6 & 8.6 & 96.6 \\
\hline & Unskilled manual & 2 & 1.1 & 1.1 & 97.7 \\
\hline & Unemployed/Housewife & 4 & 2.3 & 2.3 & 100.0 \\
\hline & Total & 175 & 100.0 & 100.0 & \\
\hline
\end{tabular}

This study also investigated whether the school factors such as infrastructure and adequacy of school equipment had influence on pupils' academic performance. 248 people including rectors, parents, teachers and pupils participated in this particular survey (Table 8).

Table 8. School information

\begin{tabular}{|c|c|c|c|}
\hline \\
\hline Variables & Description & Frequency & Percentage \\
\hline \multirow[t]{2}{*}{ Location } & Rural & 66 & $27 \%$ \\
\hline & Urban & 182 & $73 \%$ \\
\hline \multirow[t]{3}{*}{ Toilets } & Adequate & 42 & $17 \%$ \\
\hline & Inadequate & 192 & $77 \%$ \\
\hline & Not Applicable & 14 & $6 \%$ \\
\hline \multirow[t]{3}{*}{ Classrooms } & Adequate & 248 & $100 \%$ \\
\hline & Inadequate & - & - \\
\hline & Not Applicable & - & - \\
\hline \multirow[t]{3}{*}{ Workshop } & Adequate & 192 & $77 \%$ \\
\hline & Inadequate & 22 & $9 \%$ \\
\hline & Not Applicable & 34 & $14 \%$ \\
\hline \multirow[t]{3}{*}{ Library } & Adequate & 191 & $77 \%$ \\
\hline & Inadequate & 37 & $15 \%$ \\
\hline & Not Applicable & 20 & $8 \%$ \\
\hline \multirow[t]{3}{*}{ Specialist Rooms } & Adequate & 202 & $82 \%$ \\
\hline & Inadequate & 23 & $9 \%$ \\
\hline & Not Applicable & 23 & $9 \%$ \\
\hline
\end{tabular}

These school variables' characteristics were cross-checked with parent's SES and a multiple Regression was used to calculate the interrelationship of these variables (location, toilets, classrooms, workshops, library and specialist rooms) with the pupil's average score. 
Table 9. Multiple Regression analysis of some school variables versus performance of students

\begin{tabular}{|c|c|c|c|c|}
\hline \multirow{2}{*}{\multicolumn{2}{|c|}{ School information }} & Standardized Coefficients & \multirow[b]{2}{*}{$\mathbf{t}$} & \multirow[b]{2}{*}{ Sig. } \\
\hline & & \multirow[t]{2}{*}{ Beta } & & \\
\hline \multirow[t]{7}{*}{1} & & & 4.054 & .000 \\
\hline & Location & -.013 & -.157 & .875 \\
\hline & Workshop & .255 & 3.008 & .003 \\
\hline & Library & .011 & .136 & .892 \\
\hline & Classrooms adequacy & .160 & 0.880 & .350 \\
\hline & Specialist Rooms & .017 & .201 & .841 \\
\hline & Toilets adequacy & -.095 & -1.123 & .263 \\
\hline
\end{tabular}

Dependent Variable: Average Score

Table 9 shows the regression of school variables to academic performances. A $\beta$-coefficient value near zero indicates no correlation between the variables. Adequacy of classrooms (0.160) and workshops $(0.255)$ may be considered as the best predictors of positive influence on academic performance but they have no much effect on performances as such. This somehow goes in line with Nkinyangi (2003) findings that school physical facilities such as classrooms or workshops have no such effects on students' academic performance.

\subsection{Peer Pressure}

The 175 pupils' views on peer pressure were cross-tabulated with their academic performance and the results were tabulated below:

Table 10. Multiple regression of peer pressure variables against students average score

\begin{tabular}{|c|c|c|c|c|c|c|}
\hline \multicolumn{7}{|c|}{ Coefficients $^{\mathrm{a}}$} \\
\hline \multirow{2}{*}{\multicolumn{2}{|c|}{ Model }} & \multicolumn{2}{|c|}{ Unstandardized Coefficients } & \multirow{2}{*}{$\begin{array}{l}\text { Standardized Coefficients } \\
\text { Beta }\end{array}$} & \multirow[b]{2}{*}{$\mathrm{t}$} & \multirow[b]{2}{*}{ Sig. } \\
\hline & & $\mathrm{B}$ & Std. Error & & & \\
\hline \multirow[t]{5}{*}{1} & (Constant) & 19.777 & 12.215 & & 1.619 & .108 \\
\hline & Bullying & 6.325 & 4.507 & .124 & 1.403 & .163 \\
\hline & Friend's age group & .074 & 1.422 & .005 & .052 & .958 \\
\hline & Friends activities & 5.392 & 2.566 & .191 & 2.102 & .038 \\
\hline & Better with or without friends? & 1.885 & 2.834 & .063 & .665 & .507 \\
\hline
\end{tabular}

a. Dependent Variable: Average Score

Temitope and Christy (2015) mentioned that peer pressure do affect students' academic performance. Bullying $(\beta=0.101)$, their friends activities (stay at home, working, attends schools, drug dealers) having a coefficient of 0.186 are the best predictors of the influence of peer pressure on academic performance. The less students are bullied, the more positive impact will occur on their academic performance.

\subsection{Proposed measures to improve the academic performance of students}

All the respondents' views on this aspect of the study have been discussed and strategies have been proposed below:

- More involvement of educational stakeholders (teachers, parents and managers)

- More emphasis on school discipline

- Make further provisions by schools Parents-Teachers Association to provide education needs to low SES students

- Give psychological or counselling assistance to students (special funding to be invested)

- Implement a rewarding system for the students hence helping to motivate the students

- Emphasis should be put on the school atmosphere to make a conducive learning area for each and every student to be able to adapt and to make the most of the capacity

- Career guidance platform since students' young age.

3.6 Proposed leadership style to be adopted to cater for poor academic performance

In this study, one of the aims was to propose a new leadership style that can be adopted by the school management as a pilot project to cater for recent poor performances. This study findings show that parental SES do affect pupils' academic performance but other factors also lead to such poor performances including poor management (being too autocratic), lack of parental involvement, poor teaching leading to students demotivation to work. As such, schools need to: broaden "what counts"; achieve a better balance, or make a choice between competing forces; and ensure that school processes are more organic, democratic and networked (Mulford et al. 2004). Moreover, to achieve better results in schools, the "what" (products) and "how" (school processes) need to be consistent with each other (Mulford et al. 2004). 


\subsection{Leadership challenges}

The leadership challenge aims to change the school style of teaching and learning. The aim is to opt for a transformational leadership style while adhering to the Nine Year Schooling. Such style is thought to provide a more powerful way for thinking about school leadership than competing approaches (Mulford et al. 2004). According to Leithwood et al. (2004), transformational leadership seeks to increase the capacity of others to bring about the first order effects of teaching, as it empowers others within the school and facilitates collective visioning (National Research Council., 2001). As such, Leithwood et al. (2004) has illustrated the six dimensions of transformational leadership to bring about constructive academic changes (Figure 1). Moreover, it enhances teachers' motivation, changes classroom practices, bring about a collective teacher efficacy and organisational learning (OL) and has positive impacts on the pedagogy of the student although being from low or high SES (Leithwood \& Jantzi. 2005).

- $\quad$ Setting directions

- Building a shared vision

- Fostering acceptance of group goals

- High performance expectations

- Developing people

- Providing individual support and consideration

- Intellectual stimulation

- $\quad$ Providing an appropriate model

- Redesigning the organisation

- $\quad$ Building collaborative cultures

- $\quad$ Restructuring

- Building productive relationships with families and communities.

- Connecting the school to its wider environment

- Managing the instructional program.

- $\quad$ Staffing the program

- Providing instructional support

- $\quad$ Monitoring school activity

- $\quad$ Buffering staff from distractions to their work

Figure 1. Six dimensions of transformational leadership (Leithwood, 2004)

3.8 Proposed Model of Leadership - The Leadership for Organizational Learning and Student Outcomes (LOLSO) Model

Here, the model of transformational leadership contributes to organizational learning (OL) which in turns influences the teaching and learning processes. Under this model (Figure 2), staff are valued, hence bringing on more engagement and helps to care for all types of students including those coming from low SES. From the findings of this study, since we cannot change the family status of the students, changes can be brought to the school atmosphere itself, provide supports to students, empowering and valuing the staffs. These factors may help improving academic performances of especially those from low SES families who are much often devalued and lacked motivation to thrive academically. Hence, the LOLSO model helps to improve the school atmosphere. 


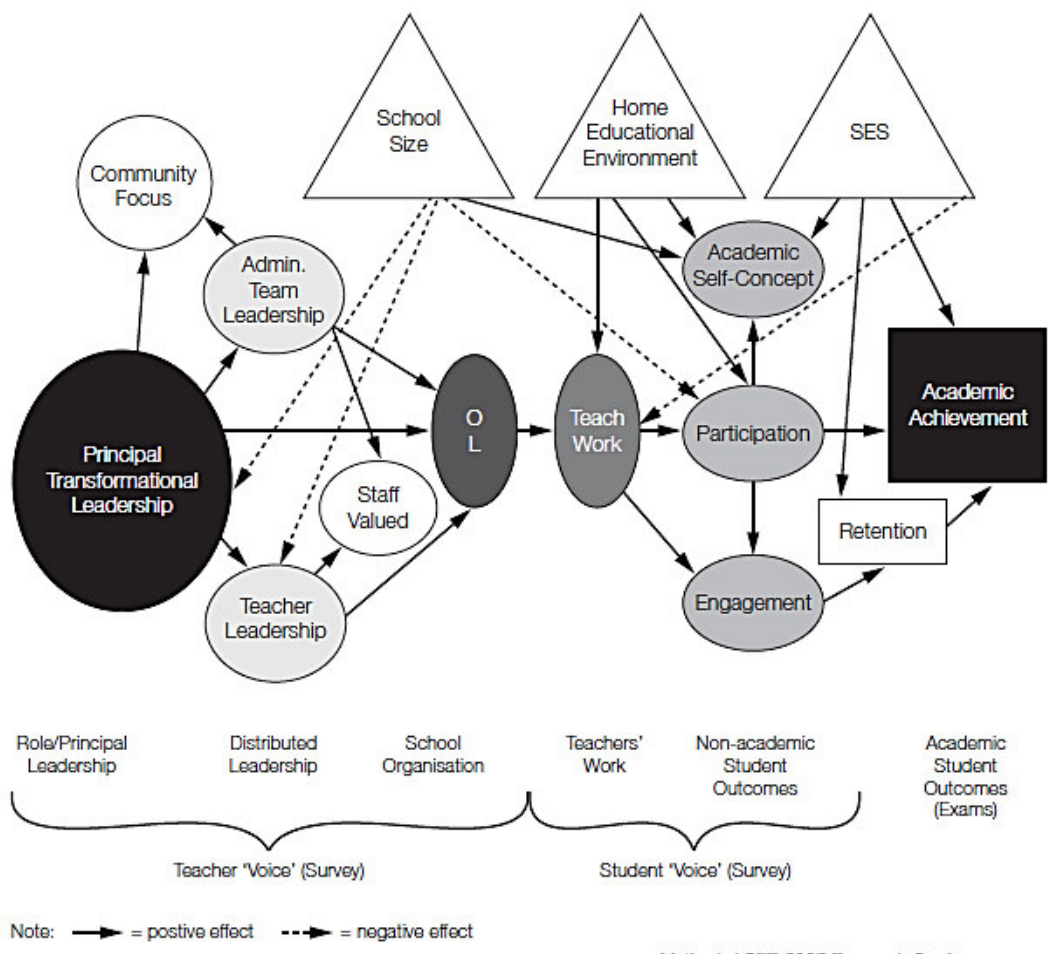

Figure 2. The Leadership for Organisational Learning and Student Outcomes (LOLSO) Model

\section{Conclusion and Recommendation}

This study investigated on the relationship between academic performance and the socio economic status (SES) in Mauritius. It looks at how the students' performances at schools were affected by social, cultural factors and economic factors. Social factors like indiscipline, sickness, lack of interest in school, broken families and substance abuse were the main factors identified to affect negatively the performance of students in schools. From the economic factors investigated, no significant difference were found between performance of the students and their parental SES. However, the academic performance of the students are more likely to be affected by the lack of implications of parents in the lives of their children being too concentrated in their works or due to their own disinterest in education. The cultural factors affecting the performance of the students being the school culture, lack of support from the community and students culture all these factors creating demotivated parents, which in turn creates a complete disinterest in the student hence leading to low academic performance. The study concluded that promoting discipline, using a new and different approach of leadership, encouraging parental involvement in school life, additional funding given from the PTA, providing a full time counsellor to students, creating a rewarding system to encourage students and career guidance at all levels are the major measures that can be put in place to help improve students' performance. Peer pressure also do have a direct impact on students' performance. Students who are bullied or have friends who do not attend school (working or drug dealers) tend to be affected negatively and hence are bound to low performance.

\section{References}

Aikens, N. L., \& Barbarin, O. (2008). Socioeconomic Differences in Reading Trajectories: The Contribution of Family, Neighborhood, and School Contexts". Journal of Educational Psychology, 100, 235-251.

Alika, H., \& Edosa, O.S. (2012). Relationship between Broken Homes and Academic Achievement of Secondary School Students in Oredo Local Government Area of Edo State, Nigeria". College student journal, 46, 256-263.

Ayoo, S. F. (2002). An Investigation of the Factors Influencing KCSE Performance in Kisumu District. Unpublished M.ED Thesis, University of Nairobi.

Baker, E.H. (2014). Socioeconomic Status, Definition. In The Wiley Blackwell Encyclopedia of Health, Illness, Behavior, and Society (eds W.C. Cockerham, R. Dingwall and S. Quah). https://doi.org/10.1002/9781118410868.wbehibs395

Bankole. F. (2019). Peer group influence on academic performance of undergraduate students in Babcock University, Ogun State. African Educational Research Journal 7, 81-87. 10.30918/AERJ.72.19.010. 
Barry, J. (2005). Effects of Socio Economic status on academic achievement. Unpublished Thesis project, Wichita State University. Retrieved from http://soar. Wichita.edu/bitstream/handle/1005/61

Central Statistical Office, Mauritius, $\quad$ (2020). Available at: http://statsmauritius.govmu.org/English/Pages/default.aspx

Darin-Mattsson, A., Fors, S. \& Kåreholt, I. (2017). Different indicators of socioeconomic status and their relative importance as determinants of health in old age, Int J Equity Health 16, 173 https://doi.org/10.1186/s12939017-0670-3

D’Mello Laveena., Monteiro Meena, \& Pinto Nelson. (2018). A Study on the Self Esteem and Academic Performance among the Students. International Journal of Health Sciences and Pharmacy (IJHSP), 2(1), 17.

Ellis, R. (2008). No Child Left Behind. The Daily Nightly.

Grissmer, D. W., Kirby, S. N. Berends, M., \& Williamson, S. (1994). Student achievement and the changing American family. Santa Monica, CA: RAND Corporation.

Hardy, L. (2006). Separate Our Pupils By Race And Income To Meet NCLB?, American School Board Journal, 193, 46-52.

National Research Council (2001). Adding It Up: Helping Children Learn Mathematics. Washington, DC: The National Academies Press. https://doi.org/10.17226/9822.

Lashbrook, J. T. (2000). Fitting in: Exploring the emotional dimension of adolescent peer pressure., PubMed 35(140): 747-757

Leithwood, K., Louis, K. S., Anderson, S. \& Wahlstrom, K. (2004). Review of research: How leadership influences student learning. NY: The Wallace Foundation.

Leithwood, K \& Jantzi, D. (2005). A Review of Transformational School Leadership Research 1996-2005. Leadership and Policy in Schools, 4. 177-199.

Machebe, C. H. \& Ifelunni, C. O. (2014). Influence of Parental Socio-Economic Status on academic achievement of Students in Selected Schools in Nigeria: A case Study of Enugu State. Journal of Education and Practice 5(2).

Makewa, L.N., Role. E. \& Otewa, F. (2012). Parental Factors Affecting Academic Achievement of Grade Six Pupils in Kisumu City, Kenya, International Journal of Asian Social Science, Asian Economic and Social Society, 2(11), 1984-1997. Retrieved from <https://ideas.repec.org/a/asi/ijoass/2012p1984-1997.html>

Mauritius examination Syndicate (2020). Education Statistics 2020, SC and HSC, November 2020. Retrieved from http://mes.intnet.mu/English/Pages/statistics_pages/sc_statistics.aspx

Morgan, P. L., Farkas, G., Hillemeier, M. M., \& Maczuga, S. (2009). Risk factors for learning-related behavior problems at 24 months of age: Population-based estimates. Journal of Abnormal Child Psychology, 37, 401413. doi:10.1007/s10802-008-9279-8

Mosha, M. A. (2017). The influence of peer group on academic performance of adolescent students in secondary schools in Tanzania, Research Journal of Educational Studies and Review, 3(1), 18-26.

Mulford, W., Silins, H., \& Leithwood, K. (2004). Educational leadership for organizational learning and improved student outcomes", Dordrecht, The Netherlands: Kluwer Academic Publishers.

Murithi, G. (2015). "Parental Determinants of Academic Performance of Learners In Public Day Secondary Schools in Imenti North Sub-County, Meru County, Kenya, (Unpublished M.Ed Thesis). Kenyatta University

Musgrave, S. (2009). What works in Schools: translating Research into Action, The Journal of Education Research, 5 (2), 76-80.

Ngatiari, J. (2011). Socio-economic factors influencing students' academic performance in secondary school in Meru South District, Kenya. (Unpublished Thesis), Moi University, Eldoret, Kenya.

Nkinyangi, S. (2003). Kenya's Bold Decision to Provide Free Primary Schooling (One Line). Available: $\mathrm{http} /$ portal.unesco.org/education

Okantey, G. (2008). Facilitating educational attainment and student achievement: Science bound parents program. Purdue Extension, Marion County. 6640 Intech BLVD. Ste.120.Indianapolis, IN 46278.

Olalekan, A. B. (2016). Influence of peer group relationship on the academic performance of students in secondary schools: A case study of selected secondary schools in Atiba Local Government Area of Oyo State. Global Journal of Human-Social Science, 16, 4.

Pridmore (2007). Adapting the primary - school curriculum for multigrade classes in developing countries: a five - step plan and an agenda for change, Journal of Curriculum Studies, 39(5), 559 576, doi: 10.1080/00220270701488093

Runs, Astrid \& Koole, Simone \& Mo-B, Johanna \& Young a Fat, Presella. (2018). The Impact of Socioeconomic Status and Participation on Student Academic Performance, Research report

Sang, C. C. (2015). Relationship between students' family Socio-economic Status, Self esteem. International Journal of Education and Research, 3(2), 647-656. 
Sirin, S. R. (2005). Socioeconomic Status and Academic Achievement: A Meta-Analytic Review of Research. Review of Educational Research, 75(3), 417-453. https://doi.org/10.3102/00346543075003417

Steinberg, L. 2005. Psychology of adolescents. New York: McGraw.

Temitope, B. E., and Christy, O. F. (2015). Influence of peer group on academic performance of secondary school students in Ekiti State. International Journal of Innovative Research and Development, 4(1), 324-331.

Usaini.I.M., \& Abubakar N.Binti. (2015). The Impact of Parents' Occupation on Academic Performance of Secondary School Students in Kuala Terengganu, Multilingual Academic Journal of Education and Social Sciences, 3(1), 112-120.

Zimring, F. (1998). American youth violence: Studies in crime and public policy. New York, NY: Oxford University Press. 